\title{
Membedah Corak Filsafat Pendidikan Muhammadiyah (Telaah Konsep Pendidik Muhammadiyah)
}

\author{
Yunita Furi Aristyasari*, Restu Faizah \\ Universitas Muhammadiyah Yogyakarta, Indonesia, Universitas Muhammadiyah \\ Yogyakarta, Indonesia \\ *Jl. Brawijaya, Geblagan, Tamantirto, Kec. Kasihan, Yogyakarta, DI. Yogyakarta 55183 \\ *Email: yunita.furi.aristyasari@umy.ac.id
}

\begin{abstract}
Muhammadiyah, which is more than a century old, does not yet have an ideal formulation that conceptualizes educators' concepts systematically. The writings related to this topic scattered in several Muhammadiyah documents as well as the article of experts or observers. This paper aims to examine the patterns of Muhammadiyah's educational philosophy so that Muhammadiyah educators can be found at the same time to elaborate on a Muhammadiyah educator concept. This paper is a qualitative methods research using a literature review. The data analysis technique uses a hermeneutical analysis. The finding is that Muhammadiyah educators can be said to be rational and pragmatic Islamists. From contemporary theory, it has an essentialist, progressive, and reconstructionist outlook. Educators must be people who have sincerity, are oriented towards real charity and benefit for others, and have an innovative and creative character in facing the challenges and problems, especially in the digital era.
\end{abstract}

Keywords: Concept of Philosophy, Muhammadiyah Educators, Ahmad Dahlan

Abstrak: Salah satu yang menjadi persoalan filosofis pendidikan adalah perbincangan mengenai pendidik. Muhammadiyah yang lebih dari satu abad belum memiliki sebuah rumusan ideal yang terkonsep dengan jelas dan tersistematis mengenai pendidik. Tulisan yang berkaitan dengan topik ini masih tersebar dalam beberapa dokumen Muhammadiyah maupun tulisan dari beberapa ahli atau pemerhati pendidikan Muhammadiyah. Tulisan ini bertujuan untuk membedah corak filsafat pendidikan Muhammadiyah sehingga dapat ditemukan corak pendidik Muhammadiyah sekaligus mengelaborasi sebuah tawaran konsep pendidik Muhammadiyah. Tulisan ini merupakan hasil penelitian dengan metode kualitatif menggunakan kajian kepustakaan. Teknik analisis data menggunakan analisis hermeneutis untuk menguji pandangan filosofis. Temuannya adalah bahwa pendidik Muhammadiyah dapat dikatakan bercorak Islamis rasional dan pragmatis. Dari perspektif teori kontemporer, ia memiliki corak esensialis, progresif, dan rekonstruksionis. Pendidik haruslah orang yang memiliki keikhlasan, berorientasi pada amal nyata dan kebermanfaatan bagi orang lain, dan memiliki karakter inovatif, kreatif dalam menghadapi tantangan dan problema kehidupan, terutama di era digital seperti saat ini.

Kata Kunci: Konsep Filsafat, Pendidik Muhammadiyah, Ahmad Dahlan

Jurnal Pendidikan Agama Islam Al-Thariqah Vol. 5, No. 2, Juli - Desember 2020

Received: 19 November 2020; Accepted 17 December 2020; Published 22 December 2020

*Corresponding Author: yunita.furi.aristyasari@umy.ac.id 


\section{PENDAHULUAN}

Salah satu kritik yang dilayangkan para pengamat pergerakan Muhammadiyah adalah bahwa sistem pendidikannya tidak didasari dengan filsafat pendidikan. Kondisi ini diungkapkan oleh (Ali, 2004: 124) bahwa untuk menyahuti dan menuntaskan problem-problem itu harus ada keberanian untuk membongkar akar permasalahan yang sesungguhnya, yaitu karena belum tersedianya orientasi filosofis pendidikan Muhammadiyah dan teori-teori pendidikan Islam dan modern. Ada dua kelemahan mendasar dalam pendidikan Muhammadiyah, yaitu pertama, umat Islam belum memperhatikan persoalan-persoalan yang terkait mutu pendidikan; kedua, pengelola baik kepala sekolah ataupun guru sekolah Islam/Muhammadiyah belum memiliki teori-teori pendidikan modern dan islami (Tafsir, 1994). Filsafat Pendidikan Muhammadiyah merupakan wacana yang terus menjadi perbincangan para ahli, seperti Ahmad Syafi'i Ma'arif, Ahmad Tafsir, Mahsun Suyuthi, Amien Rais, Abdul Munir Mulkhan, dan masih banyak lagi.

Salah satu yang menjadi persoalan filosofis adalah perbincangan mengenai pendidik dalam suatu sistem pendidikan. Suatu contoh kasus sebagai bukti bahwa Pendidikan Islam perlu memberi perhatian lebih mengenai pendidik, seperti dalam kasus penyebaran ujaran kebencian (hoax). Idealnya, kelompok terdidik dan berpendidikan tinggi, dengan kedewasaan dan kejernihan penalarannya, tidak akan menjadi korban apalagi meneruskan pesan berantai yang tidak terkonfirmasi. Namun, pada kenyataanya, banyak tokoh agama, dosen, bahkan yang bergelar doktor dan professor yang menjadi korban sekaligus pelaku penyebaran hoax dan ujaran kebencian ini (Suara Muhammadiyah, 2019). Belum lagi, dalam internal tubuh pendidikan Muhammadiyah sendiri.
Menurut Said Tuhuleley, sebagaimana dikutip oleh (Hamdan, 2009: 31) untuk menelaah lebih mendalam problematika yang dihadapi pendidikan Muhammadiyah, perlu ditempatkan dalam kerangka pendidikan Islam yang memunculkan paling sedikit tiga permasalahan penting. Salah satu dari permasalahan tersebut adalah masalah kualitas pengelolanya. Belum lagi di masa sekarang ini, Agus Priyatno menyebut saat ini ditengah masa pandemi keluhan yang disampaikan murid adalah kejenuhan cara belajar dan kesulitan dalam berinteraksi dengan guru. Menurutnya, hal ini disebabkan belum diperbaharuinya sistem dan pengetahuan tentang dunia daring dari para pendidik ("Menjaga Kualitas Pendidikan Muhammadiyah Di TengahP andemi Berita Muhammadiyah"). Oleh sebab itu, dibutuhkan suatu model pendidik yang tidak hanya bertahan dan berhasil meneruskan keberlangsungan proses pembelajaran kognitif, tetapi juga berjuang untuk keberlangsungan internalisasi afektif berupa nilai-nilai karakter Islami. Sebagaimana dinyatakan dalam sebuah adagium arab, "Aththariqatu ahammu minal maddah. Wal mudarrisu ahammu minath-thariqah". Adagium tersebut menunjukkan pentingnya posisi pendidik dalam pendidikan Islam.

Persoalan pendidik juga menjadi perhatian para ulama dan para filsuf muslim terdahulu, seperti al-Ghazali, alZarnuji, Abdullah Nashih Ulwan, Ibnu Taimiyyah, Ibnu Khaldun, Ibnu Taimiyah, dan sebagainya. Muhammadiyah sendiri sebenarnya telah merumuskan suatu rumusan dasar pendidikan Muhammadiyah yang disebut dengan Revitalisasi Pendidikan Muhammadiyah. Revitalisasi Pendidikan Muhammadiyah termuat dalam dokumen Tanfidz Keputusan Muktamar Muhammadiyah ke-46 Tahun 2010, di samping itu dokumen mengenai draft pengelolaan 
kepegawaian pada sekolah madrasah dan pondok pesantren di lingkungan pendidikan dasar dan menengah Muhammadiyah.

Sebagai salah satu gerakan pendidikan yang telah memiliki ribuan institusi pendidikan dan berjalan lebih dari satu abad, perbincangan khusus mengenai pendidik masih dirasa kurang. Setelah menelusuri beberapa tulisan yang membahas mengenai persoalan pendidik, penulis menemukan beberapa tulisan, di antaranya adalah: 1) Artikel jurnal yang ditulis oleh arif Jamali dan Lantip Diat Prasojo berjudul "Pengaruh Kompetensi Manajerial Kepala Sekolah, Lingkungan, Motivasi Guru, Terhadap Prestasi Siswa Sma Muhammadiyah Kota Yogyakarta". Artikel ini merupakan hasil penelitian yang menggunakan metode kuantitatif. Hasil penelitiannya menunjukkan terdapat pengaruh langsung antara kompetensi manajerial kepala sekolah, dengan prestasi belajar siswa SMA Muhammadiyah di Kota Yogyakarta, dengan konstribusi efektif sebesar 5,52\% (Jamali and Prasojo, 2013) 2) Artikel jurnal berjudul "Kebijakan Muhammadiyah terhadap Ordonansi guru" yang ditulis oleh Farid Setiawan. Sepanjang kemunculan dan penerapan Ordonansi Guru (baik 1905 maupun 1925), Muhammadiyah telah telah "memainkan peran politik yang sangat cantik". Permainan cantik Muhammadiyah tersebut bisa dilihat pada sikapnya yang terkadang kooperatif dan terkadang pula berseberangan terhadap Belanda (Setiawan, 2014); 3) Artikel jurnal yang berjudul "Menyemai Guru Muhammadiyah Berkemajuan Di Sekolah Muhammadiyah" ditulis oleh Mohamad Ali. Artikel tersebut menyimpulkan bahwa sekolah Muhammadiyah mengalami perkembangan dengan banyak hadirnya sekolah-sekolah model baru. Keberadaan sekolah model baru tentu memerlukan tata kelola yang baik. Masa depan sekolah model baru sangat ditentukan oleh kemampuan sekolah dalam membangun tata kelola yang baik sehingga guru-guru profesional yang berintegritas intelektual-moral-religius (baca: guru Muhammadiyah berkemajuan) kerasan untuk mendedikasikan dirinya (Ali, 2017).

Selain tulisan-tulisan di atas, sebagian besar penelitian yang membahas tentang pendidik dalam konteks pendidikan Muhammadiyah lebih banyak menggunakan metode statistik untuk meneliti suatu hubungan antara pendidik dengan aspek-aspek tertentu. Hal berbeda dalam tulisan ini adalah pembahasan yang dikemukakan lebih filosofis dengan menawarkan sebuah konstruksi filosofis unsur pendidik dalam sistem pendidikan Muhammadiyah. Pembahasan mengenai unsur pendidik dalam ruang filsafat pendidikan Muhammadiyah yang dilakukan secara terpisah penting untuk dilakukan karena ia berfungsi sebagai jangkar praktik bagi pendidik Muhammadiyah dalam menghadapi arus deras zaman yang disruptif. Lebih tegasnya, Abdul Munir Mulkhan (2020, h. 5) mengungkapkan bahwa filsafat Pendidikan Muhammadiyah sebagai jangkar turbulensi Pendidikan ketika prakteknya nanti tidak lagi butuh gedung, tidak lagi butuh guru yang hadir secara fisik, dan seabrek mata pelajaran seperti yang ada sekarang. Oleh sebab itu, tulisan ini bertujuan untuk: pertama, membedah corak pendidik dalam sistem pendidikan Muhammadiyah melalui pendekatan filsafat; kedua, melakukan elaborasi terhadap corak pendidik Muhammadiyah yang lebih adaptif terhadap dengan kondisi zaman.

\section{KONSEP TEORI}

Filsafat pendidikan sebagai pelaksanaan pandangan filsafat dan kaidah-kaidah filsafat dalam bidang pengalaman kemanusiaan yang disebut 
dengan pendidikan (Al-Syaibany, 1979). Filsafat pendidikan adalah ilmu yang pada hakekatnya merupakan jawabanjawaban pandangan dalam lapangan pendidikan dan merupakan suatu penerapan analisa filosofis terhadap lapangan pendidikan (Barnadib, 1982).

Sementara filsafat pendidikan Islam merupakan suatu formula filsafat pendidikan yang berasaskan sumbersumber Islam, baik sumber yang bersifat normatif maupun historis. Sumber normatif berasal dari wahyu berupa alQur'an dan hadis Nabi, sementara sumber historis berasal dari jejak-jejak penelusuran filsafat pendidikan Islam. Berikut beberapa definisi yang dikemukakan oleh para ahli mengenai filsafat pendidikan Islam. Filsafat pendidikan Islam sebagai pemikiran yang radikal dan mendalam tentang berbagai masalah yang ada hubungannya dengan pendidikan Islam (Ramayulis, 2015). Filsafat pendidikan Islam atau filsafat tarbiyah tidak bisa dirumuskan jika filsafat Islam belum ada. Filsafat tarbiyah merupakan motor penggerak bagi proses pendidikan dengan cara yang berbeda dan tujuan-tujuan tertentu. Dalam peta pemikiran filsafat tarbiyah, Muhammad Jawwad Ridla (2002: 74) mengungkapkan tiga aliran dalam filsafat tarbiyah, yakni aliran konservatif, religious-rasional, dan pragmatis.

Hal yang tidak boleh dilupakan bahwa Muhammadiyah lekat dengan KH. Ahmad Dahlan sebagai peletak dasar pendidikan Muhammadiyah. Berikut beberapa pemikiran Ahmad Dahlan yang terrangkum menjadi Tujuh Falsafah dan ajaran KH. Ahmad Dahlan dalam buku karya K.R.H. Hadjid (2004: 3-15).

Pelajaran pertama, kita manusia ini, hidup di dunia hanya sekali, untuk bertaruh. sesudah mati akan mendapat kebahagiaankah atau kesengsaraankah? Pelajaran kedua, Kebanyakan diantara manusia berwatak angkuh, dan takabur, mereka mengambil keputusan sendiri- sendiri. Pelajaran ketiga, Manusia itu kalau mengerjakan pekerjaan apapun, sekali, dua kali, berulang-ulang maka kemudian jadi biasa. Kalau sudah menjadi kesenangan yang dicintai, maka kebiasaan yang dicintai itu sukar untuk di robah. Pelajaran keempat, Manusia perlu digolongkan menjadi satu dalam kebenaran, harus bersama-sama mempergunakan akal fikirannya untuk berfikir, bagaimana sebenarnya hakikat dan tujuan manusia hidup di dunia. Apakah perlunya? hidup di dunia harus mengerjakan apa? dan mencari apa? dan apa yang dituju? Manusia harus mempergunakan akal fikirannya untuk mengoreksi soal i'tikad dan kepercayaannya, tujuan hidup dan tingkah lakunya, mencari kebenaran yang sejati, karena kalau hidup di dunia hanya sekali ini sampai sesat, akibatnya akan celaka dan sengsara selama-lamanya. Pelajaran kelima, Setelah manusia mendengarkan pelajaran-pelajaran fatwa yang bermacam-macam membaca beberapa tumpuk buku dan sesudah memperbincangkan, memikir-mikir, menimbang, membanding-banding kesana kemari, barulah mereka itu dapat memperoleh keputusan, memperoleh barang yang benar yang sesungguhsungguhnya. Dengan akal fikirannya sendiri dapat mengetahui dan menetapkan inilah perbuatan yang benar. Pelajaran keenam, Kebanyakan pemimpin-pemimpin rakyat, belum berani mengorbankan harta benda dan jiwanya untuk berusaha tergolongnya umat manusia dalam kebenaran. Malah pemimpin-pemimpin itu biasanya hanya mempermainkan, memperalat manusia yang bodoh-bodoh dan lemah. Pelajaran ketujuh, Pelajaran terbagi kepada dua bagian, yaitu belajar ilmu (pengetahuan dan teori) dan belajar amal (mengerjakan, mempraktekkan). Semua pelajaran harus dengan cara sedikit demi sedikit, setingkat demi setingkat. 
Pokok-pokok filsafat pendidikan Muhammadiyah dapat ditemukan dalam dokumen Tanfidz Keputusan Muktamar Muhammadiyah ke-46 Tahun 2010. Dalam rumusan mengenai filsafat pendidikan Muhammadiyah tersebut juga disebutkan bahwa pendidikan Muhammadiyah merupakan pendidikan Islam modern yang mengintegrasikan agama dengan kehidupan dan antara iman dan kemajuan yang holistik. Pendidikan Muhammadiyah memiliki visi terbentuknya manusia pembelajar yang bertaqwa, berakhlak mulia, berkemajuan dan unggul dalam IPTEKS sebagai perwujudan tajdid dakwah amar ma'ruf nahi munkar.

Misi pendidikan Muhammadiyah dalam Tanfidz Keputusan Muktamar Satu Abad (Muhammadiyah, 2010) dirumuskan dalam tujuh poin: (1) Mendidik manusia memiliki kesadaran ketuhanan (spiritual makrifat). Membentuk manusia berkemajuan yang memiliki etos tadjid, berfikir cerdas, alternatif dan berwawasan luas. (3) Mengembangkan potensi manusia berjiwa mandiri, beretos kerja keras, wirausaha, kompetetif dan jujur. (4) Membina peserta didik agar menjadi manusia yang memiliki kecakapan hidup dan ketrampilan sosial, teknologi, informasi dan komunikasi. (5) Membimbing peserta didik agar menjadi manusia yang memiliki jiwa, kemampuan. (6) Menciptakan dan mengapresiasi karya seni-budaya. (7) Membentuk kader persyarikatan, ummat dan bangsa yang ikhlas, peka, peduli dan bertanggungjawab terhadap kemanusiaan dan lingkungan.

Di dalam ilmu pendidikan yang dimaksud pendidik ialah semua yang mempengaruhi perkembangan seseorang, yaitu manusia, alam, dan kebudayaan. Dalam konsep pendidkan Islam, pendidik sering disebut dengan istilah murabbi, Muallim, dan muaddib (Izzan, 2016). Murabbi merupakan term yang menunjukkan pendidik melakukan tarbiyah. Muallim merupakan term yang menunjukkan pendidik melakukan ta'lim. Sementara, muaddib menunjukkan bahwa pendidikan melakukan proses pendidikan yang disebut dengan $t a^{\prime} d i b$.

Pendidik yang mengabdi pada lembaga pendidikan Muhammadiyah adalah pendidik yang memiliki kompetensi dasar sebagai pendidik yang didukung oleh komitmennya pada ideologi persyarikatan Muhammadiyah, nilai-nilai dan pemahaman keislaman sebagaimana yang dipahami (Muhammadiyah, 2010). Kompetensi dasar yang dimaksud adalah kompetensi akademik, kompetensi pedagogik, kompetensi atau komitmen ideologi persyarikatan, kompetensi sosial dan kompetensi kepribadian.

Dalam konteks pendidikan Muhammadiyah, pendidik juga diharapkan memiliki pemahaman mengenai pendidikan akhlak, pendidikan individu dan pendidikan kemasyarakatan. Pendidikan moral (akhlak) sebagai sarana untuk menanamkan karakter pembelajar yang sesuai dengan nilai-nilai Islam; pendidikan individu sebagai usaha untuk menumbuhkan kesadaran individu yang utuh; dan pendidikan kemasyarakatan sebagai usaha menumbuhkan kesediaan dan keinginan hidup bermasyarakat (Muhammadiyah, 2010).

\section{METODE PENELITIAN}

Penelitian ini menggunakan jenis penelitian deskripsi dengan metode kualitatif menggunakan sumber kepustakaan. Sumber data primer berasal dokumen Tanfidz Keputusan Muktamar Muhammadiyah ke-46 Tahun 2010 dan Falsafah Ajaran K.H. Ahmad Dahlan. Proses analisis data dilakukan dengan tahapan sesuai dengan teori Miles dan Huberman dalam Kurniawan, (2018, h. 241), yaitu dimulai dari pengumpulan data, reduksi data, penyajian data, dan penarikan kesimpulan. Teknik analisis 
data menggunakan analisis hermeneutis untuk menguji pandangan filosofis dengan menggunakan teori Aliran pendidikan kontemporer George Kneller dan George R. Knight serta Teori Aliran pendidikan Islam Muhammad Jawwad Ridla.

\section{HASIL DAN PEMBAHASAN \\ Pendidik Muhammadiyah dalam Konteks Filsafat Pendidikan Islam}

Secara struktural filsafat pendidikan Muhammadiyah ialah turunan atau fungsi dari filsafat pendidikan Islam atau filsafat tarbiyah (Mulkhan and Abror, 2019). Untuk mengkaji filsafat pendidikan Muhammadiyah, maka perlu dipahami terlebih dahulu apa itu filsafat pendidikan dan filsafat pendidikan Islam.

Jika digambarkan dalam sebuah bagan, maka hubungan antara filsafat pendidikan dengan filsafat pendidikan Islam dan hubungannya dengan filsafat pendidikan Muhammadiyah sebagai berikut:

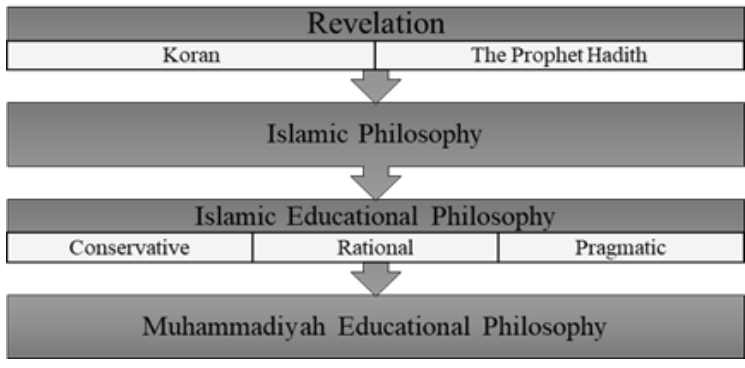

Gambar 1.

Bagan struktur Filsafat Pendidikan Islam

Dari Bagan tersebut, terlihat gambaran bahwa filsafat Muhammadiyah merupakan bermuara dari filsafat pendidikan Islam. Bagan tersebut juga menunjukkan bahwa filsafat pendidikan Islam secara garis besar mengandung tiga aliran pemikiran, yaitu konservatif, rasional, dan pragmatis. Aliran ini berdasarkan klasifikasi yang digagas oleh Muhammad Jawwad Ridla.

Pertama, aliran konservatif. Aliran ini dalam bergumul dengan persoalan pendidikan cenderung bersikap murni keagamaan (Ridla, 2002). Kelompok aliran konservatif memaknai ilmu-ilmu cenderung bersifat sempit dan hirarkis. Mereka menganggap bahwa ilmu yang dibutuhkan di dunia saat ini adalah ilmu yang dibutuhkan di akhirat nanti, dengan kata lain ilmu agama. Oleh sebab itu, alQur'an dan al-Hadis menjadi ilmu-ilmu pertama yang harus dipelajari. Kedua, Aliran rasional. Pemikiran aliran rasional memiliki kesamaan dengan aliran sebelumnya, yaitu aliran konservatif. Perbedaannya yang cukup mencolok adalah pemikirannya tentang aspek ilmu dan belajar. Kelompok aliran rasional mengakui keragaman kebutuhan manusia, sebagai implikasinya bahwa ilmu pengetahuan harus mengakomodasi keragaman kebutuhan ragam tersebut. Selanjutnya, aliran ini menegaskan bahwa kebutuhan-kebutuhan manusia dan lingkungan material tidak kalah penting dibanding dengan kebutuhan rohaniahnya (Ridla, 2002). Oleh sebab itu, jenis-jenis ilmu pengetahuan yang dapat memfasilitasi kebutuhan-kebutuhan material tersebut harus benar-benar diakomodir. Ketiga, aliran pragmatis. Pemikiran kelompok aliran ini lebih bersifat aplikasi-praktis. Salah satu pemikir dalam aliran ini adalah Ibnu Khaldun. Dia mengklasifikasikan ilmu pengetahuan berdasar tujuan fungsionalnya, bukan berdasar nilai substansialnya semata (Ridla, 2002). Ibnu Khaldun sebagai salah satu kalangan pragmatis, menurut Jawwad Ridla, mengakomodir ragam keilmuan yang nyata terkait dengan kebutuhan langsung manusia, baik berupa kebutuhan spiritual-rohaniah maupun kebutuhan material-jasmaniah. Jika dihubungkan dengan konsep aliran pendidikan di atas, maka sebenarnya filsafat pendidikan Muhammadiyah dapat disebut corak pendidikan yang rasional sekaligus pragmatis.

Sebagaimana yang diketahui bahwa gagasan pendidikan Muhammadiyah bermula dari ide-ide dan nilai-nilai 
perjuangan Kiai Haji Ahmad Dahlan. Kiai Haji Ahmad Dahlan disebut dengan sosok yang pragmatis. Pragmatis di sini bukan berarti penganut aliran pragmatisme dalam filsafat. Sifat pragmatis Kiai Haji Ahmad Dahlan ditunjukkan dengan perhatian beliau dalam mengutamakan pengamalan ajaran-ajaran Islam. Sifat pragmatisme Kiai Haji Ahmad Dahlan juga mampu mengaktualisasikan ide dan gagasannya tersebut ke dalam sebuah gerakan pendidikan, yaitu sekolah atau madrasah saat itu. Pragmatisme dalam pendidikan Kiai Haji Ahmad Dahlan juga tampak dalam ajaran ketujuh dalam falsafah Kiai Haji Ahmad Dahlan, yaitu Pelajaran terbagi kepada dua bagian, yaitu belajar ilmu (pengetahuan dan teori) dan belajar amal (mengerjakan, mempraktekkan). Semua pelajaran harus dengan cara sedikit demi sedikit, setingkat demi setingkat.

Sementara, gerakan pendidikan Kiai Haji Ahmad Dahlan dapat dimasukkan dalam aliran rasional. Rasionalisme Kiai Haji Ahmad Dahlan tampak dalam ajaran keempatnya, yang berbunyi "Manusia perlu digolongkan menjadi satu dalam kebenaran, harus bersama-sama mempergunakan akal fikirannya untuk berfikir, bagaimana sebenarnya hakikat dan tujuan manusia hidup di dunia. Apakah perlunya? hidup di dunia harus mengerjakan apa? dan mencari apa? dan apa yang dituju? Manusia harus mempergunakan akal fikirannya untuk mengoreksi soal i'tikad dan kepercayaannya, tujuan hidup dan tingkah lakunya, mencari kebenaran yang sejati, karena kalau hidup di dunia hanya sekali ini sampai sesat, akibatnya akan celaka dan sengsara selama-lamanya".

Watak rasionalis tersebut juga ditunjukkan dalam ajaran kelima falsafah K.H. Ahmad Dahlan yang berbunyi sebagai berikut: "Dengan akal fikirannya sendiri dapat mengetahui dan menetapkan inilah perbuatan yang benar".
Dalam proses pembelajarannya, Kiai Haji Ahmad Dahlan memadukan pembelajaran umum dan pembelajaran agama. Seiring berjalannya waktu sistem pembelajaran ini menjadi cikal bakal madrasah di Indonesia. Menengok historisitas kiprah Kiai Haji Ahmad Dahlan dalam pendidikan, tampak bahwa beliau sangat menghargai ilmu-ilmu umum atau keduniaan dan menempatkannya sama pentingnya dengan ilmu agama. Oleh karena itu misi pendidikan beliau adalah mewujudkan sosok kyai-intelek atau intelek-kyai. Kedua istilah tersebut menampilkan seorang figur yang tidak hanya menampakkan sosok yang memiliki pengetahuan agama, tetapi juga memiliki wawasan pengetahuan yang luas. Hal ini diperjelas dalam Tanfidz keputusan Muktamar (Muhammadiyah, 2010) dijelaskan bahwa "Pendidikan Muhammadiyah adalah penyiapan lingkungan yang memungkinkan seseorang tumbuh sebagai manusia yang menyadari kehadiran Allah swt sebagai Robb dan menguasai ilmu pengetahuan, teknologi dan seni (IPTEKS)".

Implikasi watak pendidikan Muhammadiyah menurut kerangka pemikiran Jawwad Ridha tersebut berimplikasi watak pendidik Muhammadiyah. Pendidik yang berwatak rasionalitik dalam konteks pemahaman Muhammadiyah secara implisit memiliki keselarasan dengan pendidik rasional menurut Ikhwan al-shafa-sebagai kelompok yang mewakili kelompok rasional-religius. Ikhwan al-Shafa menempatkan setiap pendidik pada posisi strategis dan inti dalam kegiatan pendidikan. Mereka mempersyaratkan kecerdasan, kedewasaan, kelurusan moral, ketulusan hati, kejernihan pikir, etos keilmuan dan tidak fanatik buta pada diri pendidik (Ridla, 2002).

Kecerdasan seorang pendidik dalam konteks saat ini bermakna terpenuhinya kompetensi profesional. Jika mengacu 
pada Undang-undang pendidik oleh pemerintah, salah satu kompetensi yang tidak disebutkan dalam rumusan filsafat pendidik Muhammadiyah tersebut adalah kompetensi profesional. Kompetensi profesional adalah kemampuan penguasaan materi pembelajaran secara luas dan mendalam (Undang-Undang Nomor 14 Tahun 2005 Tentang Guru Dan Dosen, n.d. Pasal 10). Meski filsafat pendidikan Muhammadiyah tidak mencantumkan kompetensi profesional, pendidik Muhammadiyah tetap didorong untuk meningkatkan kompetensi dan profesionalisme, serta kualifikasi akademiknya, sebagaimana yang tercantum dalam Tanfidz Keputusan Muktamar Muhammadiyah mengenai Rencana strategis pendidik (Muhammadiyah, 2010).

Etos keilmuan yang dipersyaratkan bagi para pendidik Muhammadiyah ditunjukkan dengan getolnya Muhammadiyah terhadap untuk mendorong para pendidik tidak hanya mempelajari ilmu agama, tetapi sekaligus juga ilmu pengetahuan umum. Ilmu pengetahuan umum dianggap mendukung kemajuan zaman saat ini, sebagaimana yang dilakukan oleh Ahmad Dahlan. Ahmad Dahlan sebagai pelopor pendidikan Muhammadiyah memandang bahwa pendidik dalam pendidikan Islam bukan hanya yang memiliki ilmu agama. Dalam Kongres Islam Besar di Cirebon yang dikutip dari oleh Mulkhan dan Abror (2019, h. 270) bahwa: (a) Masing-masing orang Islam wajib meratakan (menyebarkan) ilmunya, jadi wajib menyebarkan agama Islam, baik ulama, bahkan orang Islam yang baru sedikit ilmunya. Di sini dapat dilihat bahwa Kiai Ahmad Dahlan tidak ingin bahwa penyebaran ilmu hanya monopoli para kiai dan ulama. (b) Orang Islam yang belum pandai harus belajar ke yang pandai. Jadi orang Islam itu bersifat dua yaitu sifat guru dan sifat murid. Dalam hal ini, seorang pendidik dapat memfungsikan dirinya sebagai pembelajar dan pembelajar dapat memfungsikan dirinya sebagai guru. Ahmad Dahlan menerapkan pembelajaran sepanjang hayat dengan konsep guru dan murid seperti tersebut. (c) Kesempatan belajar dan mengajar itu dimana-mana.

Aspek kelurusan moral dan ketulusan hati seiring dengan kompetensi kepribadian yang dibutuhkan seorang guru. Selain memiliki penguasaan materi, seorang pendidik tersebut juga harus memiliki pengetahuan dasar mengenai akhlak, karakter atau moral. Pengetahuan tersebut tentunya berdasarkan sumber al-Qur'an yang sesuai dengan faham Muhammadiyah. Selain memiliki pengetahuan dasar, pendidik Muhammadiyah juga perlu memiliki kompetensi kepribadian yang ditunjukkan melalui sikap dan perilaku serta mengacu pada nilai-nilai akhlak dalam al-Qur'an dan Hadis.

Terakhir adalah persyaratan kejernihan berpikir dan tidak fanatik buta pada diri pendidik juga menjadi perhatian yang ditekankan oleh Ahmad Dahlan dalam falsafahnya dalam pelajaran keempat, yaitu "Manusia perlu digolongkan menjadi satu dalam kebenaran, harus bersama-sama mempergunakan akal fikirannya untuk berfikir" serta pelajaran kelima, yaitu "Dengan akal fikirannya sendiri dapat mengetahui dan menetapkan inilah perbuatan yang benar".

Corak pendidikan Muhammadiyah juga dapat dikatakan pragmatis. Hal yang menjadikan pendidik Muhammadiyah bercorak pragmatis adalah bahwa pendidik Muhammadiyah didorong untuk menekankan pembelajaran pada proses pengamalan atau praktik. Ini terlihat dalam ajaran falsafah Ahmad Dahlan ketujuh, yaitu pelajaran terbagi ke dalam dua bagian, pertama adalah belajar ilmu. Kedua adalah belajar amal. Belajar amal inlah yang dimaksud dengan 
mengerjakan dan mempraktekkan. Pada prinsipnya corak pragmatis tersebut memang memiliki beberapa titik kesamaan dengan corak rasionalis. Hanya saja, kaum pragmatis memiliki tujuan dan orientasi pendidikan yang lebih bersifat aplikasi-praktis. Ibnu Khaldun sebagai seorang yang juga dikatakan pragmatis menurut Jawwad Ridla (2002 h. 186), ia mengungkapkan bahwa prestasi atau keberhasilan dalam pembelajaran adalah malakat (profesionalitas), dan karenanya terbentuk melalui proses latihan dan keseriusan.

Keterpaduan antara ilmu dan amal sebenarnya juga ditekankan oleh kalangan konservatif, semisal al-Ghazali. Ia menyerupakan guru sejati dengan matahari yang menyinari sekelilingnya, dan dengan minyak wangi (misk) yang membuat harum di sekitarnya (Ridla, 2002). Meskipun begitu, pemikiran Ahmad Dahlan lebih condong pada pragmatisme daripada konservatif sebagaimana dikatakan (Majid, 2020).

$$
\text { Namun, pada hakikatnya }
$$
pragmatisme yang ditekankan oleh Kiai Haji Ahmad Dahlan berbeda dengan pragmatisme Ibnu Khaldun. Pragmatisme Kiai Haji Ahmad Dahlan lebih berorientasi pada pengamalan dari ilmu yang dipelajari, yaitu ilmu agama. Sementara, pragmatisme Ibnu Khaldun lebih kepada mengakomodasi ilmu-ilmu yang lebih kepada bermanfaat langsung bagi kehidupan. Ridla (2002, h. 185) mengatakan bahwa kecenderungan pragmatis dalam pemikiran Ibnu Khaldun kiranya masih belum eksplisit, kecuali bila dilihat juga idenya memasukkan pengajaran (program kurikuler) sejumlah keterampilan praktis, yakni ia mengedepankan corak aplikasi praktis dalam proses pembelajaran.

Selain yang disebutkan di atas, Menurut Ibnu Khaldun, sebagaimana dikutip Ridla (2002, 191) bahwa pengajaran ragam keilmuan hanya akan berguna bila dilakukan secara gradual sedikit demi sedikit. Perlunya konsep pembelajaran gradual disepakati oleh Ahmad Dahlan sebagaimana yang telah diungkapkan dalam falsafah pelajaran ketujuh, yaitu "Semua pelajaran harus dengan cara sedikit demi sedikit, setingkat demi setingkat".

Di samping itu corak pragmatisme pendidik Muhammadiyah juga tampak pada penekanan kemampuan komparatif yang dimiliki seorang pendidik, di antaranya adalah kemampuan melaksanakan pendidikan masyarakat. Pendidikan masyarakat mengharuskan seorang pendidik menyelanggarakan sebuah proses pembelajaran yang dapat mendorong peserta didik untuk dapat dan bersedia mengaktualisasikan ilmunya dalam hidup bermasyarakat.

Keberhasilan seorang pendidik untuk melaksanakan pendidikan individu dipengaruhi oleh kualifikasi dirinya, yaitu terpenuhinya kompetensi kepribadian dan sosial. Kompetensi kepribadian adalah kemampuan kepribadian yang mantap, berakhlak mulia, arif, dan berwibawa serta menjadi teladan peserta didik (Undang-Undang Nomor 14 Tahun 2005 Tentang Guru Dan Dosen. Pdf, n.d., h. pasal 10).

Sementara keberhasilan seorang pendidik melaksanakan pendidikan masyarakat dipengaruhi oleh kompetensi sosial. Kompetensi sosial merupakan kemampuan guru untuk berkomunikasi dan berinteraksi secara efektif dan efisien dengan peserta didik, sesama guru, orangtua/wali peserta didik, dan masyarakat sekitar ("Undang-Undang Nomor 14 Tahun 2005 Tentang Guru Dan Dosen. Pdf" pasal 10).

\section{Pendidik Muhammadiyah dalam Konteks Filsafat Pendidikan Kontemporer}

Pendidikan yang menghidupkan merupakan teoritisasi dari pandangan Ahmad Dahlan terhadap manusia dan pendidikan. Konsep Guru dan murid yang diistilahkan dengan "pembelajar" belum 
bisa begitu saja dikatakan sebagai pendidikan sepanjang hayat. Pendidik yang juga berperan sebagai pembelajar memiliki peran dan fungsi mencari dan memberikan ilmu pengetahuannya kepada peserta didik. Supaya pengetahuan yang diberikan mampu membawa nilai, maka ia harus memiliki manfaat untuk kehidupan sosial masyarakat. Oleh sebab itu, tugas pendidik adalah mendorong tumbuhnya kesadaran peserta didik melalui pengaktifan akal mereka untuk dapat memecahkan baik individu dan sosial.

Jika diperhatikan, konsep pendidik ini memang masih sejalan dengan pemikiran progresivisme. Pendidik progresif selalu melatih anak didiknya untuk mampu memecahkan problemproblem yang ada dalam kehidupannya (Muhmidayeli, 2013). Pandangan ini sesuai dengan konsep pembelajaran sepanjang hayat bahwa pengetahuan manusia perlu diaktualisasikan dalam kehidupan nyata. Maka, tugas pendidik dalam pandangan Muhammadiyah adalah mendorong peserta didik untuk mengaktualisasikan ilmu pengetahuannya untuk bisa memecahkan persoalan-persoalan keumatan, sebagaimana yang dilakukan oleh Kiai Ahmad Dahlan.

Namun, dalam pandangan penulis peran pendidik dalam pandangan progresif menjadi tergeser menjadi hanya sebagai fasilitator dan monitor saja. Hal ini tentu merupakan implikasi dari pandangan progresivisme yang menolak otoritarianisme. Progresivisme tidak mengakui kemutlakan kehidupan, menolak absolutisme dan otoritarisme dalam segala bentuknya, nilai-nilai yang dianut bersifat dinamis dan selalu mengalami perubahan (Ramayulis, 2015).

Dalam praktik perjalanan pendidikan Muhammadiyah hingga saat ini tidak berjalan sebagaimana yang dianut oleh pendidikan progresivisme. Dalam aspek pendidik, penulis lebih sepakat pandangan Muhammadiyah lebih sejalan dengan pandangan esensialisme. Dalam hal ini tugas guru adalah sebagai agen untuk memperkuat pembentukan kebiasaan dalam rangka penyesuaian dengan lingkungan tersebut (Muhmidayeli, 2013). Jika progresif memandang bahwa peserta didik sebagai pusat pembelajaran. Maka, tidak demikian halnya dengan esensialis. Esensialis memandang bahwa guru atau pendidiklah yang menjadi pusat pembelajaran. Jika merunut perjalanan dan pandangan Ahmad Dahlan, memang ditemukan bahwa Ahmad Dahlan merupakan seorang progresif dengan beberapa perubahan-perubahan yang dikemukakannya. Namun, praktik pengajaran yang dilakukan oleh Ahmad Dahlan tetap berpihak pada esensialis. Mengapa? Karena proses pendidikan tetap berada dalam kendali pendidik. Hal ini dikarenakan fokus Ahmad Dahlan saat itu adalah membersihkan tauhid dan menumbuhkan kesadaran akal mengenai kondisi sosial dan keagamaan yang sedang mengalami kemunduran saat itu. Tentu dengan kondisi seperti itu tidak bisa dilakukan hanya dengan peran fasilitator saja, melainkan guru tetap berperan sebagai pendidik yang menentukan dan mengarahkan materi dan jalannya proses pembelajaran. Yunan Yusuf mengungkapkan bahwa peranan guru tidak secara langsung melainkan sebagai penasihat (Hamdan, 2009).

Mengenai praktik pendidikan Muhammadiyah saat ini meskipun sudah cenderung mengarah pada pendekatan SCL (student centered learning) yang lebih berpihak pada progresivisme, tetapi guru tetap menjadi poros yang menentukan kebijakan, baik mengenai aspek kurikulum maupun proses pembelajaran yang dilaksanakan. Bagi kalangan Muhammadiyah, guru atau pendidik tetap menjadi sosok yang perlu mendapat tempat terhormat oleh para peserta didik. 
Inilah yang dikenal dengan adab bagi kalangan muslim.

Karakter pembelajaran yang holistik dan terintegrasi setidaknya dapat dibagi dalam dua ranah adab yang penting, yaitu: pertama, adab kepada Allah dan Rasulullah Saw. dan kedua, adab kepada orang lain atau masyarakat (Sayuti et al., 2020). Dalam pendidikan Islam, termasuk pendidikan Muhammadiyah, adab kepada guru atau murid menjadi aspek yang mendapat perhatian besar dalam proses pembelajaran. Abror mengatakan bahwa menuntut ilmu dengan mematuhi dan menjalankan adab-adab kebaikan tidak lain merupakan Langkah pengejawantahan paling rasional dari nilai-nilai Islam (Sayuti et al., 2020). Salah satu aspek esensialisme adalah bentuk rasa hormat kepada guru. Jika rasa hormat tidak datang, guru memiliki hak dan tanggung jawab untuk menata tatanan kedisiplinan yang akan membawa ke arah suasana yang kondusif untuk proses belajar yang tertib (Knight, 2007).

Pandangan Muhammadiyah mengenai pemenuhan kompetensi yang perlu dipenuhi oleh guru juga menjadi pertimbangan bagi kaum esensialis. Dalam Tanfidz Keputusan Muktamar Satu Abad (Muhammadiyah, 2010) disebutkan bahwa pendidik yang mengabdi pada lembaga pendidikan Muhammadiyah adalah pendidik yang memiliki kompetensi dasar sebagai pendidik yang didukung oleh komitmennya pada ideologi persyarikatan Muhammadiyah, nilai-nilai dan pemahaman keislaman sebagaimana yang dipahami Muhammadiyah. Para progresivis terlalu menekankan pada aspek kebebasan dan kepentingan individu (peserta didik) sehingga kurang perhatiannya pada aspek kompetensi pendidik yang diperlukan ke arah tujuan tersebut. Di sisi lain, para esensialis memberikan perhatian terhadap kompetensi-kompetensi yang harus dipenuhi oleh pendidik. Ramayulis (2015: 61) mengatakan bahwa para tokoh esensialisme sepakat dengan apa yang dikemukakan oleh progresivisme bahwa belajar tidak akan sukses tanpa didasarkan pada berbagai kapasitas, interes dan tujuan subjek belajar, namun aliran ini yakin bahwa kesemuanya ini harus melalui keterampilan mengajar guru, baik dalam merencanakan dan mengorganisasi subjek-subjek materi, maupun dalam memahami proses pengembangan pendidikan. Keterampilan ini memiliki keterkaitan erat dengan kompetensi pedagogis dan keterampilan professional seorang guru.

Di samping itu, sebagai implikasi dari pandangan esensialisme mengenai konsep peserta didik sebagai manusia yang utuh, maka seorang pendidik perlu mengenali dan memiliki konsep pandangan yang utuh tentang peserta didik sebagai manusia. Dalam pandangan Muhammadiyah, hal ini menuntut pemahaman keislaman seorang guru yang utuh khususnya pandangan Islam tentang manusia. Pandangan keislaman yang utuh akan mempengaruhi pemahaman guru tentang bagaimana mengaktualisasikan kompetensi pedagogis, kompetensi sosial dan kompetensi kepribadiannya. Dalam Peraturan Menteri Pendidikan Nasional Nomor 16 Tahun 2007 disebutkan bahwa kompetensi pedagogis adalah menguasai karakteristik peserta didik dari aspek fisik, moral, spiritual, sosial, kultural, emosional, dan intelektual (Nasional, 2007). Sedangkan, kompetensi sosial adalah kemampuan guru untuk berkomunikasi dan bergaul secara efektif dengan peserta didik, tenaga kependidikan, orang tua/wali peserta didik, dan masyarakat sekitar. Kompetensi profesional adalah penguasaan materi pembelajaran secara luas dan mendalam, yang mencakup penguasaan materi kurikulum mata pelajaran di sekolah dan substansi keilmuan yang menaungi materinya, serta penguasaan terhadap struktur dan 
metodologi keilmuannya. Terakhir adalah kompetensi kepribadian adalah kemampuan personal yang mencerminkan kepribadian yang mantap, stabil, dewasa, arif dan berwibawa, menjadi teladan bagi peserta didik, dan berakhlak mulia. Di samping, komitmen lain yang harus dipegang oleh pendidik adalah nilai-nilai persyarikatan dan nilainilai keislaman yang dipahami oleh Muhammadiyah. Komitmen terhadap nilai-nilai yang absolut menjadi salah satu poin pokok yang disangkal oleh kaum progresivis, namun tidak bagi esensialis. Sejalan dengan pandangan dari Muhammadiyah tersebut, esensialisme merupakan filsafat pendidikan tradisional yang memandang nilai-nilai pendidikan hendaknya bertumpu pada nilai-nilai yang jelas dan tahan lama, sehingga memiliki kestabilan dan arah yang jelas (Muttaqin, 2013). Dalam pandangan Islam, nilai-nilai yang baku dan stabil tersebut bersumber dari nilai-nilai ketuhanan yang termuat dalam wahyuNya.

Pandangan kaum esensialis memandang bahwa pendidik perlu menerapkan sikap disiplin dan menanamkan rasa hormat kepada orang yang lebih tua. Hal ini merupakan implikasi dari pandangan esensialisme bahwa sekolah-sekolah mengajarkan dan melatih anak-anak secara aktif tentang nilai-nilai kedisiplinan, kerja keras, dan rasa hormat kepada pihak yang berwenang atau orang yang memiliki otoritas (Boiliu, 2013).

Di samping wajah esensialis yang terdapat dalam konsep pendidik Muhammadiyah, penulis menemukan aspek-aspek filsafat rekonstruksionisme di dalamnya. Dalam hal pemenuhan kompetensi sosial, kompetensi pedagogis, dan kompetensi profesional, pandangan Muhammadiyah juga sejalan dengan filsafat rekonstruksionisme. Kinsley Price menggarisbawahi bahwa guru harus dapat meyakinkan subjek didiknya akan kemampuannya dalam memecahkan masalah, sehingga masalah yang ada dalam subject matters dapat diatasi (Ramayulis, 2015). Di samping itu, para rekonstruksionis menganggap untuk menumbuhkembangkan keinginan belajar subjek didik, guru harus mampu mengenali setiap diri subjek didik secara individu. Guru juga harus dapat menciptakan kondisi kelas sedemikian rupa sehingga interaksi guru dengan peserta didik dan semua yang hadir dalam kelas dapat berkomunikasi dengan baik.

Aspek-aspek rekonstruksionisme juga tampak dalam filsafat Ahmad Dahlan mengenai pelajaran keenam, yaitu keberanian berkorban dan berjuang untuk kepentingan orang lain. Perjuangan Ahmad Dahlan untuk melawan corak otokrasi dalam sistem pendidikan saat itu juga menunjukkan bahwa ia adalah seorang pendidik yang rekonstruksionis. Keberanian untuk tampil merubah tatanan merupakan salah satu corak rekonstruksionis sebagaimana dikatakan bahwa guru harus berani berbeda pandangan sebagai lambang dari suatu kreativitas dalam memberikan solusi terhadap persoalan-persoalan yang disajikan (Ramayulis, 2015).

\section{Formulasi Pendidik Muhammadiyah}

Setelah membahas tipe atau corak pendidik Muhammadiyah baik dari perspektif Islam maupun perspektif kontemporer, maka penting kiranya membuat sebuah formula konsep pendidik yang dapat mencakup keseluruhan corak di atas, namun tetap dalam bingkai filsafat pendidikan Muhammadiyah.

Konsep pendidik Muhammadiyah tidak bisa dilepaskan dari pandangan Kiai Haji Ahmad Dahlan tentang khalifah. Tentu saja pandangan ini bukan tanpa alasan karena sejatinya tujuan pendidikan Islam adalah untuk mewujudkan atau menghasilkan manusia yang mampu mengemban perannya 
sebagai khalifah di muka bumi. Hal ini diamini oleh Izzan (2016: 95) bahwa pendidik adalah orang yang bertanggung jawab memberi bimbingan atau bantuan kepada anak didik dalam perkembangan jasmani dan rohani agar mencapai kedewasaan, mampu melaksanakan tugasnya sebagai makhluk Allah, khalifah di muka bumi, sebagai makhluk individu dan makhluk sosial.

Dalam pengertian Kiai Dahlan, khalifah adalah orang yang mengerti baik-buruk, benar-salah, kebahagiaan atau penderitaaan, dan bertindak atas dasar pengertian itu (Mulkhan and Abror, 2019). Khalifah dalam pandangannya adalah manusia yang berpikir sesuai fakta, cermat, kritis, meletakkan relativitas kebenaran iptek dan mencari kebenaran yang lebih bermanfaat bagi hidup semua orang. Aditya Pratama dalam Mulkhan and Abror (2019, h. 127) menambahkan bahwa manusia yang dicita-citakan oleh Kiai Dahlan dan Muhammadiyah adalah manusia yang sesuai kodratnya, yaitu manusia yang berakal sehat dan memiliki etos welas asih dan kesederhanaan.

Dari pandangan kekhalifahan yang dikemukakan di atas serta mengkompromikannya dengan corakcorak pendidik, baik dari perspektif teori pendidikan Islam maupun teori pendidikan kontemporer, maka konsep pendidik Muhammadiyah memiliki karakter-karakter, yaitu; (a) Pendidik Muhammadiyah harus mensucikan niat dan hati dalam melaksanakan tugas dan tanggung jawabnya. Menurut Kiai Dahlan "dalam menentukan baik-buruk, betulsalah hanyalah hukum yang sah dan sesuai dengan hati yang suci", lanjutnya.... "tidak ada gunanya pangkat yang tinggi kecuali dengan hati yang suci" (Mulkhan and Abror, 2019). Semboyan "Hidup hidupilah Muhammadiyah, jangan mencari kehidupan di Muhammadiyah" menunjukkan bahwa pendidik Muhammadiyah jangan sampai memiliki orientasi materi dalam pekerjaannya. (b) Pendidik Muhammadiyah adalah orang yang selalu ingin dan tidak pernah berhenti belajar dan memotivasi peserta didik untuk terus belajar (pembelajar). Perhatian yang begitu besar terhadap akal harus didorong dengan belajar dan menuntut ilmu. Kiai Ahmad Dahlan, sebagaimana dikutip oleh Muhammad Sulaiaman dalam Mulkhan and Abror (2019: 270) bahwa orang itu harus dan wajib mencari tambahan pengetahuan, jangan sekali-kali merasa cukup dengan pengetahuannya sendiri, apalagi menolak pengetahuan orang lain. Konsep pendidik adalah pembelajar berimplikasi bahwa pendidik harus selalu menjadikan dirinya selalu ingin maju dan meningkatkan kualitas dirinya termasuk mempelajari, memahami dan memanfaatkan kecanggihan teknologi di masa. (c) Pendidik Muhammadiyah adalah orang yang mampu memadukan ilmu dengan amalnya. Sikap ini harus ia contohkan dalam dirinya dan ia tanamkan dalam diri peserta didik. Muhammad Sulaiman dalam Mulkhan and Abror (2019: 270) mengutip pernyataan Kiai Ahmad Dahlan bahwa orang itu perlu dan wajib menjalankan pengetahuannya yang utama, jangan sampai hanya tinggal pengetahuan saja. Di sinilah letak pendidikan individu yang harus dilaksanakan oleh pendidik. Keterpaduan antara ilmu dan amal akan menumbuhkan keseimbangan antara jasmani dan rohani. (d) Pendidik Muhammadiyah adalah orang yang selalu ingin memberikan manfaat bagi dirinya dan juga bagi masyarakat. Hal ini mengingat bahwa penyelenggaraan pendidikan di lingkungan Muhammadiyah perlu memperhatikan nilai manfaat sebagai upaya pemenuhan prinsip-prinsip sosial kemanusiaan (aspek sosiologis) sehingga output lembaga pendidikan Muhammadiyah memiliki kontribusi nyata bagi masyarakat (Mulkhan and Abror, 2019). 
Kiai Haji Ahmad Dahlan dapat dijadikan figur contoh oleh para pendidik Muhammadiyah. Kesucian hati, kecerdasan akal pikiran dan pengamalan ilmu beliau memberikan manfaat bagi orang lain, dengan membangun rumah yatim, panti asuhan dan lembaga pendidikan. (e) Seorang pendidik Muhammadiyah memiliki karakter berani, inovatif dan kreatif. Sudah menjadi sebuah keharusan untuk dapat menghadirkan pendidikan Islam yang inovatif, kreatif, unggul dan berkualitas agar dapat sejalan dengan zaman yang ada dan mampu berkompetisi dengan lembaga pendidikan lainnya (Al Faruq, 2020). Oleh sebab itu, ruh tajdid dalam Muhammadiyah harus mampu dijiwai oleh pendidik Muhammadiyah sehingga ia tidak hanya berperan sebagai pendidik, tetapi juga menjadi pembaharu yang inovatif, kreatif, dan berani berbeda pandangan dalam memberikan solusi atas persoalan-persoalan kehidupan.

\section{PENUTUP}

Pendidikan dalam Muhammadiyah merupakan derivasi dari filsafat pendidikan Muhammadiyah yang dapat dikaji dari berbagai dokumen, seperti hasil pemikiran Kiai Haji Ahmad Dahlan yang terrekam dalam falsafah ajaran Kiai Haji Ahmad Dahlan dan terformulasikan lebih sistematis dalam Tanfidz Keputusan Muktamar Muhammadiyah tahun 2010. Dari kajian mengenai dua dokumen tersebut dapat dilihat bagaimana corak pendidikan Muhammadiyah dan hal itu berimplikasi ke dalam corak pendidik Muhammadiyah.

Pendidik Muhammadiyah memiliki corak Islampragmatis dan Islam-rasional. Dari tinjauan pendidikan kontemporer, Pendidik Muhammadiyah memiliki corak esensialis, progresif dan juga rekonstruksionis. Dari corak-corak tersebut, pendidik Muhammadiyah adalah pendidik yang memiliki keikhlasan hati dalam bekerja, mampu memotivasi diri untuk meningkatkan kualitas hidupnya (pembelajar) sekaligus menjadi motivator bagi peserta didik, memberikan keteladanan dalam amal dan akhlak, memiliki orientasi kebermanfaatan bagi masyarakat, bersikap inovatif dan kreatif dalam menghadapi problema dan tantangan zaman.[]

\section{DAFTAR RUJUKAN}

Menjaga Kualitas Pendidikan Muhammadiyah di Tengah Pandemi-Berita Muhammadiyah." Menjaga Kualitas Pendidikan Muhammadiyah di Tengah Pandemi-Berita Muhammadiyah, 2020.

Indonesia, Presiden Republik. "Undangundang Republik Indonesia Nomor 14 Tahun 2005 tentang Guru dan Dosen." (2006).

Al Faruq, Umar. "Peluang Dan Tantangan Pendidikan Muhammadiyah Di Era 4.0." Ar-Risalah: Media Keislaman, Pendidikan Dan Hukum Islam, vol. 18, no. 1, 2020, pp. 013-030.

Ali, Mohamad, and Marpuji Ali. "Filsafat Pendidikan Muhammadiyah: Tinjauan Historis Dan Praksis." (2004).

Ali, Mohamad. "Menyemai guru Muhammadiyah berkemajuan di sekolah Muhammadiyah." Ishraqi 1.1 (2017): 1-10.

Al-Syaibany. Omar Muhammad al-Toumy. Falsafah Pendidikan. Bulan Bintang, 1979.

Barnadib, Imam. Filsafat Pendidikan Pengantar Mengenai Sistem Dan Konsep. 1982.

Boiliu, Noh Ibrahim. "Peran Pendidik Terhadap Kelakuan Murid Dalam Perspektif Filsafat Esensialisme." Jurnal Dinamika Pendidikan, vol. 6, no. 2, 2, Fakultas Keguruan dan llmu Pendidikan Universitas Kristen Indonesia, July 2013, pp. 65-71. 
Hamdan. Paradigma Baru Pendidikan Muhammadiyah. Ar-Ruzz Media, 2009.

Izzan, Ahmad. Hadis Pendidikan: Konsep Pendidikan Berbasis Hadis. Humaniora, 2016.

Jamali, Arif, and Lantip Diat Prasojo. "Pengaruh Kompetensi Manajerial Kepala Sekolah, Lingkungan, Motivasi Guru, Terhadap Prestasi Siswa SMA Muhammadiyah Kota Yogyakarta." Jurnal Akuntabilitas Manajemen Pendidikan, vol. 1, no. 1, 2013, pp. 8-21.

K.R.H. Hadjid. Ajaran K.H. Ahmad Dahlan Dengan 17 Kelompok Ayat AlQur'an. PWM Jawa Tengah, 2004.

Knight, George R. Filsafat Pendidikan (Issues and Alternatives in Educational Philosphy). Translated by Mahmud Arif, Gama Media, 2007.

Kurniawan, Asep. Metodologi Penelitian Pendidikan. Remaja Rosdakarya, 2018.

Majid, Nuur Wachid Abdul. "Pendidikan Berkemajuan: Konsep Pemikiran KH Ahmad Dahlan dalam Menghadapi Era Multidigital Artikel Muhammadiyah, 2020.

Pimpinan Pusat Muhammadiyah. "Tanfidz Keputusan Muktamar Satu Abad Muhammadiyah." Yogyakarta: PP Muhammadiyah, 2010.

Muhmidayeli. Fllsafat Pendidikan. Refika Aditama, 2013.

Mulkhan, Abdul Munir, and Robby Habiba Abror. Jejak-Jejak Filsafat Pendidikan Muhammadiyah: Membangun Basis Etis Filosofis Bagi Pendidikan. Majelis Diktilitbang PP Muhammadiyah, 2019.

Mulkhan, Abdul Munir. Memahami Fungsi FPI Dan FPM. Webinar "FIlsafat Pendidikan Islam Berkemajuan," Universitas Ahmad Dahlan Yogyakarta.

Muttaqin, Labib. "Aplikasi Teori Double Movement Fazlur Rahman Terhadap Doktrin Kewarisan Islam Klasik." Al-
Manahij: Jurnal Kajian Hukum Islam 7.2 (2013): 195-206.

Nasional, Kementrian Pendidikan. "Permendiknas No. 16 Tahun 2007." Tentang Standar Kualifikasi Akademik Dan Kompetensi Guru. Jakarta: Depdiknas, 2007.

Ramayulis. Filsafat Pendidikan Islam: Analisis Filosofis Sistem Pendidikan Islam. Kalam Mulia, 2015.

Ridla, Muhammad Jawwad. Tiga Aliran Utama Teori Pendidikan Islam: Perspektif Sosiologis -Filosofis. Translated by Mahmud Arif, Tiara Wacana, 2002.

Sayuti, Muhammad, et al. Adab Mahasiswa Di Perguruan Tinggi Muhammadiyah Dan 'Aisyiyah. Majelis Diktilitbang PP Muhammadiya, 2020.

Setiawan, Farid. "Kebijakan pendidikan Muhammadiyah terhadap ordonansi guru." Jurnal Pendidikan Islam 3.1 (2014): 47-70.

Suara Muhammadiyah. "Pendidikan dan Keadaban Bangsa." Suara Muhammadiyah, vol. 12, June 2019, p. 08.

Tafsir, Ahmad. Ilmu Pendidikan Dalam Perspektif Islam. Rosdakarya, 1994. 